\title{
The juxtamembrane but not the carboxyl-terminal domain of the insulin receptor mediates insulin's metabolic functions in primary adipocytes and cultured hepatoma cells
}

K Paz ${ }^{1}$, S Boura-Halfon ${ }^{1}$, L S Wyatt ${ }^{2}$, D LeRoith $^{3}$ and Y Zick ${ }^{1}$

${ }^{1}$ Department of Molecular Cell Biology, The Weizmann Institute of Science, Rehovot 76100, Israel

${ }^{2}$ Laboratory of Viral Diseases, National Institute of Allergy and Infectious Diseases, National Institutes of Health, Bethesda, Maryland 20892, USA

${ }^{3}$ Molecular and Cellular Endocrinology Branch, National Institute of Diabetes, Digestive and Kidney

Diseases, National Institutes of Health, Bethesda, Maryland 20892, USA

(Requests for offprints should be addressed to Y Zick; Email: lizick@weizmann.weizmann.ac.il)

\begin{abstract}
Insulin-stimulated signaling pathways are activated upon interactions between the intracellular domains of the receptor and its downstream effectors. Insulin receptor substrate proteins (IRS-1, -2, -3 and -4) are the best-studied substrates for the insulin receptor kinase (IRK). We have previously shown that IRS-1 and IRS-2 interact with the juxtamembrane (JM) but not with the carboxyl-terminal (CT) region of the insulin receptor (IR) in vitro. However, the precise role of these IR regions in mediating insulin's bioeffects is still unresolved. In the present work we made use of vaccinia virus as a vector for quantitative expression of the JM and CT domains within the cytoplasm of physiologically insulin-responsive primary rat adipocytes and rat hepatoma Fao cells. We could demonstrate that overexpression of either the $\mathrm{JM}$ or the CT domains did not inhibit either insulin binding or insulin-stimulated receptor autophosphorylation. In contrast, metabolic effects such as insulin-induced glucose utilization in adipocytes,
\end{abstract}

and insulin-induced amino acid utilization in Fao hepatoma cells were inhibited (70-80\%) in cells overexpressing the JM but not the CT domains of IR. The inhibitory effects of the overexpressed JM domain were accompanied by inhibition of insulinstimulated IRS-1 phosphorylation, decreased IRS-1-associated PI3K activity, and decreased phosphorylation of the downstream effectors of PI3K, PKB and p70 S6K. Insulin-stimulated thymidine incorporation in Fao cells was also inhibited (40\%) upon overexpression of the JM but not the CT region of IR. Our findings suggest that interactions between the JM region of IR and its downstream effectors are obligatory for insulin-stimulated metabolic functions in physiologically relevant insulin responsive cells. They also rule out the possibility that interaction of proteins, including PI3K, with the $\mathrm{CT}$ domain can provide an alternative pathway. Fournal of Molecular Endocrinology (2000) 24, 419-432

\section{INTRODUCTION}

The insulin receptor (IR) is a Tyr-specific protein kinase (IRK) that undergoes autophosphorylation following insulin binding. The activated receptor phosphorylates substrate proteins on multiple Tyr residues to further propagate insulin signal transduction and insulin action (Cheatham \& Kahn 1995). The major targets of insulin receptor kinase (IRK) are the insulin receptor substrates (IRS-1, -2, -3 and -4) (Sun et al. 1991, 1995, Lavan et al. 1997a,b) and Shc (Pronk et al. 1993). IRS proteins contain a conserved pleckstrin homology (PH) domain (Haslam et al. 1993, Mayer et al. 1993) at their amino terminus, followed by a P-Tyr binding (PTB) domain that functions as the IR binding region (Eck et al. 1996). The C-terminal region of IRS proteins contains multiple Tyr phosphorylation motifs that serve as docking sites for SH2 domain-containing signaling proteins like the $\mathrm{p} 85 \alpha$ regulatory subunit of PI3K (phosphatidylinositol 3-kinase), and other adaptors like Grb2, Nck, Crk, Fyn and SHP-2, which are involved in insulin signal transduction (Cheatham \& Kahn 1995, 
White 1997). Activation of PI3K leads to phosphorylation and activation of several Ser/Thr kinases, such as PDK (Alessi et al. 1997, Stokoe et al. 1997), protein kinase B (PKB; Alessi et al. 1996) and p70 S6K (Alessi et al. 1998) that mediate the metabolic and growth-promoting effects of insulin (Alessi et al. 1997), including glucose uptake and lipogenesis, protein synthesis and cell survival (Cheatham \& Kahn 1995, White 1997). The relative roles of the different IRS proteins in mediating insulin action are still unclear, however studies of gene disruption revealed that IRS-2 compensates for the absence of IRS-1 in hepatocytes of IRS-1 null mice, while IRS-3 provides an alternative pathway for PI3K activation in adipocytes of these animals (Patti et al. 1995, Yamauchi et al. 1996, Smith et al. 1997). In contrast, IRS-2 null mice are severely glucose intolerant, suffer from impaired pancreatic $\beta$-cell functions, and develop classical type II diabetes (Withers et al. 1998).

Several structural regions have been defined within the intracellular part of the IR $\beta$ subunit. These are the juxtamembrane (JM) region, the kinase region, and the carboxyl-terminal (CT) region (Ebina et al. 1985, Ullrich et al. 1985). The JM region $\left(\mathrm{Arg}^{940}-\mathrm{Leu}^{987}\right)$ contains $\mathrm{Tyr}^{960}$ within a L-X - -NPXYXSXSD motif. Mutation of $\mathrm{Tyr}^{960}$ to Phe or Ala decreases IR binding to IRS-1 (Gustafson et al. 1995) and IRS-2 (Chaika et al. 1999), impairs receptor signal transmission, and reduces the sensitivity and maximal responsiveness of cells transfected with the mutated IR, both to the metabolic and growth-promoting effects of insulin (Kaburagi et al. 1993, White et al. 1988, Chaika et al. 1999). This occurs even though autophosphorylation in other receptor regions is normal and the IRK is fully active in vitro (White et al. 1988, Kaburagi et al. 1993). The PTB domain of IRS proteins binds the NPEY motif within the JM region of IR (Eck et al. 1996), and these PTB-JM interactions are required for insulin-induced $\mathrm{Tyr}$ phosphorylation of IRS proteins (Gustafson et al. 1995, Sharma et al. 1997). Conversely, an isolated $\mathrm{JM}$ region of IR, but not its $\mathrm{CT}$ region, is sufficient to mediate quantitative interactions with IRS proteins in vitro (Paz et al. 1996, 1997), indicating that the JM domain contains all the structural information required for interaction with IRS proteins.

The C'T region of IR (Leu ${ }^{1245}-\mathrm{Ser}^{1343}$ ) contains two autophosphorylation sites at $\mathrm{Tyr}^{1316}$ and $\mathrm{Tyr}^{1322}$ whose role in receptor signaling is still unresolved (Tavare \& Siddle 1993). It has been postulated that autophosphorylation of this region generates docking sites for several adaptor proteins, including the $\mathrm{p} 85 \alpha$ regulatory subunit of $\mathrm{PI} 3 \mathrm{~K}$ (Levy et al. 1994), whose direct binding to the carboxyl terminus region of IR could contribute to the effects of insulin on PI3K activity (Levy et al. 1994). Indeed, Chinese hamster ovary (CHO) cells expressing a receptor mutant whose $\mathrm{C}$-terminal 43 amino acids (including these $\mathrm{Tyr}$ residues) were deleted $\left(\mathrm{IR}_{43}\right)$, display a compromised ability to stimulate glucose transport and glycogen synthesis (Maegawa et al. 1988), whereas mitogenic signaling and stimulation of the IRK activity remain intact (Maegawa et al. 1988). Likewise, cells expressing a chimeric IGF-I receptor whose $\mathrm{CT}$ domain is replaced by that of the IR, manifest IGF-I-stimulated glycogen synthesis and MAP kinase activity in correlation with the activity of the IR (Faria et al. 1994). The CT domain has been implicated in IRS-1independent functions: it is an important element in mediating the effects of insulin on protein phosphatase-1 activity (Begum et al. 1993), and its phosphorylated $\operatorname{Tyr}^{1322}$ serves as the binding site for the SH2 domain of the adaptor protein Grb10 (Hansen et al. 1996).

Hence, while it is clear that the IR has the ability to induce diverse signals through distinct receptor regions, the exact role of the JM and $\mathrm{CT}$ regions of IR in mediating insulin action is not well defined. The difficulty stems from the fact that at least part of the relevant information was gathered from studies carried out in cells that are not physiological targets of insulin action. Primary adipocytes are a major target tissue for insulin action, however these fully differentiated cells are not readily amenable to genetic manipulations. Although introduction of foreign cDNAs into adipocytes by electroporation has been reported (Quon et al. 1994, Tanti et al. $1997)$, the relatively low yield $(\sim 10 \%)$ of the transfected cells required co-transfection with a reporter gene (e.g. HA-Glut4) whose translocation was monitored. Hence, no other effects of the transfected proteins could be studied. Previous studies have also reported on the successful infection of cultured 3T3-L1 adipocytes with vaccinia (Chen et al. 1997) or adeno-viruses (Sharma et al. 1997), however this system was not tested on primary adipocytes. To address this issue we set out to develop a system for gene transduction and protein overexpression in primary adipocytes using vaccinia virus. Individually expressed receptor domains were introduced into insulin responsive primary adipocytes and rat hepatoma Fao cells, utilizing recombinant vaccinia virus-mediated infection. Our findings suggest that interactions between the JM region of IR and its downstream effectors are obligatory 


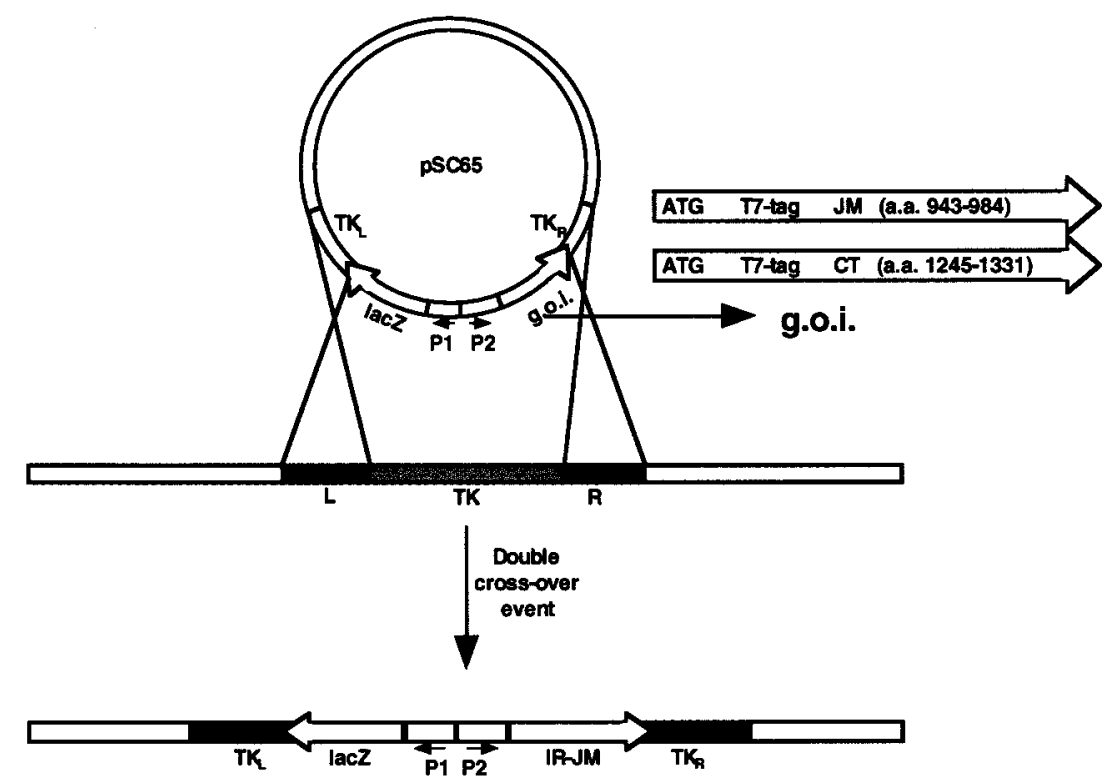

FIGURE 1. Schematic representation of recombinant vaccinia virus construction. The transfer vector, pSC65, contains vaccinia virus DNA sequences, $\mathrm{TK}_{\mathrm{L}}$ and $\mathrm{TK}_{\mathrm{R}}$, that flank the genes coding for lacZ and for our gene of interest (g.o.i.) (the JM or CT regions of IR). BSC-1 cells were infected with vaccinia viruses prior to transfection with recombinant pSC65 plasmid. A double crossover event occurred between the $\mathrm{TK}_{\mathrm{L}}$ and $\mathrm{TK}_{\mathrm{R}}$ sequences and the homologous regions of the virus ( $L$ and $R)$. This resulted in the generation of a recombinant virus into which lac $Z$ and IR-JM or IR-CT genes were inserted. Recombinant viruses defined as Vcc- $\beta$-Gal, Vcc-CT and Vcc-JM were generated in such a manner.

for insulin-stimulated metabolic functions in physiologically relevant insulin responsive cells. Our results also rule out the possibility that interaction of proteins, including PI3K, with the $\mathrm{CT}$ domain can provide an alternative pathway.

\section{MATERIALS AND METHODS}

\section{Materials}

Recombinant human insulin was a gift from Novo-Nordisk (Copenhagen, Denmark). Wheat Germ Agglutinin-Agarose beads and protease inhibitor cocktail were from Sigma Chemicals Co. (St Louis, MO, USA). BrdU was from Calbiochem (La Jolla, CA, USA), and X-Gal was purchased from Promega (Madison, WI, USA). Lipofectamin and Optimem were from GIBCO-BRL (Grand Island, NY, USA). Dinonylphtalate oil was purchased from ICN Biomedicals Inc. (Aurora, OH, USA). Collagenase was obtained from Worthington Biochemical Co. (Freehold, NJ, USA).

\section{Antibodies}

Monoclonal P-Tyr (PY-20) and polyclonal IR antibodies were obtained from Transduction Labs (Lexington, KY, USA). Polyclonal IRS-1 antibodies were prepared as described previously (Hadari et al. 1992). Monoclonal T7-tag antibodies were obtained from Novagene Inc. (Madison, WI, USA). Polyclonal phospho-specific PKB and p70 S6K antibodies were obtained from BioLab (Beverly, MA, USA). Polyclonal PKB antibodies were purchased from Sigma Chemicals Co. Polyclonal p $85 \alpha-P I 3 K$ antibodies were obtained from Upstate Biotechnology (Lake Placid, NY, USA).

\section{Generation of recombinant vaccinia virus}

DNA corresponding to the $\mathrm{JM}$ or the $\mathrm{C} T$ region of IR (a.a. 943-984 and 1245-1331 respectively), tagged by immunogenic sequence derived from T7 bacteriophage, was subcloned into a plasmid transfer vector, pSC65 (Chakrabarti et al. 1997, Moss \& Earl 1991), using 5' Bgl-II site and 3' Kpn-I site (see Fig. 1). Within pSC65, the genes of 
interest (g.o.i.) are flanked by DNA from nonessential region of the vaccinia virus genome, that enables homologous recombination between the genes of interest and the vaccinia virus gene. BSC-1 (ATCC\#CCL26) cells $\left(10^{6}\right.$ cells $/ 30 \mathrm{~mm}$ dish) were infected at a multiplicity of infection (m.o.i.) of $0.05 \mathrm{pfu}$ (plaque-forming units) per cell with wildtype vaccinia virus. After a $2 \mathrm{~h}$ incubation at $37{ }^{\circ} \mathrm{C}$ the medium was discarded and the cell monolayers were transfected with $5 \mu \mathrm{g}$ pSC65, pSC65-JM or pSC65-CT, using Lipofectin. Forty-eight hours post infection the cells were harvested by discarding the medium (save for $1 \mathrm{ml}$ ) and scraping the cells off the well using a rubber stick. Cells were ruptured by three cycles of freezing and thawing and were sonicated for $30 \mathrm{~s}$ using a bath sonicator. HuTK ${ }^{-} 143 \mathrm{~B}$ cells (ATCC\#CRL8303, $10^{6}$ cells $/ 30 \mathrm{~mm}$ dish) were incubated with $10^{-1}, 10^{-2}$ and $10^{-3}$ dilutions of BSC-1 cell extracts in $1 \mathrm{ml}$ minimum essential medium (MEM) containing $2 \%$ fetal calf serum (FCS), in a $\mathrm{CO}_{2}$ incubator at $37^{\circ} \mathrm{C}$. After $2 \mathrm{~h}$ incubation the medium was discarded, and $2 \mathrm{ml}$ 'plaque-medium' (1\% LMP agarose in MEM medium containing $5 \%$ FCS), containing $25 \mu \mathrm{g} / \mathrm{ml}$ $\mathrm{BrdU}$ were added, and incubation in a $\mathrm{CO}_{2}$ incubator at $37^{\circ} \mathrm{C}$ was continued. Forty-eight hours later, $2 \mathrm{ml}$ 'plaque-medium' containing $25 \mu \mathrm{g} / \mathrm{ml}$ BrdU and $0 \cdot 4 \% \mathrm{X}-\mathrm{Gal}$ were added, and incubation was continued for $6-12 \mathrm{~h}$ in a $\mathrm{CO}_{2}$ incubator at $37^{\circ} \mathrm{C}$, until blue plaques appeared. The blue plaques were picked with pipette into $0.5 \mathrm{ml}$ MEM medium containing $10 \% \mathrm{FCS}$, and the cells were ruptured by three cycles of freezing and thawing followed by a $30 \mathrm{~s}$ sonication in a bath sonicator. The extracts served for another cycle of infection of $\mathrm{HuTK}^{-}$ 143B cells as described above. Following three selection cycles, plaques were picked up, frozen and thawed three times and sonicated for $30 \mathrm{~s}$. Hela S3 (ATCC\#CCL2.2) cells $\left(10^{8}\right.$ cells $/ 150 \mathrm{~mm}$ dish), were incubated for 3 days in a $\mathrm{CO}_{2}$ incubator at $37^{\circ} \mathrm{C}$ with $2 \mathrm{ml}$ MEM medium containing 10\% FCS and $10^{-2}$ dilution of $\mathrm{HuTK}^{-} 143 \mathrm{~B}$ cells extract. Seventy-two hours post infection the cells were harvested by discarding the medium, adding $2 \mathrm{ml}$ fresh MEM medium containing 2\% FCS, and scraping the cells off the plate using a rubber stick. Cells were frozen and thawed three times and were sonicated for $30 \mathrm{~s}$ using a bath sonicator. These extracts served as the recombinant vaccinia virus stock $(4 \cdot 5-$ $8.5 \times 10^{9} \mathrm{pfu} / \mathrm{ml}$ ), and were subsequently used for infection.

\section{Generation of primary adipocytes culture}

Male 6-7 week-old Wistar rats were decapitated. The distal halves of the epididymal fat pads were pooled and isolated fat cells were prepared by incubation of the tissue with collagenase at $37^{\circ} \mathrm{C}$ for $1 \mathrm{~h}$, as described (Cushman \& Salans 1978, Lawrence \& Larner 1978), save for the fact that $1 \%$ insulin-free BSA was added to the digestion buffer. The cells were gently filtered through mesh, and were washed several times with Krebs Ringer buffer (KRB) $\left(100 \mathrm{mM} \mathrm{NaCl}, 4 \mathrm{mM} \mathrm{KH}_{2} \mathrm{PO}_{4}, 2 \mathrm{mM}\right.$ $\mathrm{MgSO}_{4}, 10 \mathrm{mM} \mathrm{NaHCO}, 1 \mathrm{mM} \mathrm{CaCl}, 30 \mathrm{mM}$ Hepes, pH 7.4) to get rid of blood cells, undigested tissue, and excess of collagenase.

\section{Infection of primary adipocytes}

Primary adipocytes were prepared by collagenase digestion (Cushman \& Salans 1978). The cytocrite was adjusted to $50 \%$ in $\mathrm{KRB}$ buffer, and fractions of $0.2 \mathrm{ml}\left(10^{6}\right.$ cells $)$ were incubated with $10^{7}$ m.o.i. recombinant vaccinia virus at $37^{\circ} \mathrm{C}$ for $1 \mathrm{~h}$. At the end of incubation, cells were washed once with KRB buffer and once with Dulbecco's modified Eagle's medium (DMEM) medium, and were further incubated for 5-24 h in DMEM medium containing $1 \%$ insulin-free $\mathrm{BSA}$ in a $\mathrm{CO}_{2}$ incubator at $37^{\circ} \mathrm{C}$.

\section{Infection of Fao cells}

Fao cells were grown in RPMI medium supplemented with $10 \%$ fetal calf serum. Confluent monolayers, grown in $60 \mathrm{~mm}$ dishes $\left(10^{7}\right.$ cells $)$ were incubated with $10^{8}$ m.o.i. recombinant vaccinia virus at $37{ }^{\circ} \mathrm{C}$ for $1 \mathrm{~h}$. At the end of incubation cells were washed twice with RPMI medium, and were further incubated for 5-24 h in serum-free RPMI medium in a $\mathrm{CO}_{2}$ incubator at $37^{\circ} \mathrm{C}$.

\section{Assay of $\beta$-galactosidase activity}

Infected cells were grown in $35 \mathrm{~mm}$ dishes. Cells were washed with PBS, incubated with $1 \mathrm{ml}$ fixation solution ( $2 \%$ formamide, $0 \cdot 2 \%$ glutaraldehyde) for $10 \mathrm{~min}$ at $4{ }^{\circ} \mathrm{C}$, and were washed twice with PBS. Following fixation, $1 \mathrm{ml}$ staining solution $(5 \mathrm{mM}$ potassium ferricyanide, $5 \mathrm{mM}$ potassium ferrocyanide, $2 \mathrm{mM}$ magnesium chloride, $1 \mathrm{mg} / \mathrm{ml}$ $\mathrm{X}-\mathrm{Gal}$ in PBS) was added to each well, for an incubation of $10-60 \mathrm{~min}$ at $37^{\circ} \mathrm{C}$. When blue color was observed, cells were washed with distilled water to stop the reaction.

\section{Insulin-induced amino acid uptake and utilization in Fao cells}

Confluent Fao cells in $35 \mathrm{~mm}$ dishes were incubated in serum-free RPMI medium for $16 \mathrm{~h}$. Cells were then treated with $100 \mathrm{nM}$ insulin for $3 \mathrm{~h}$ at $37^{\circ} \mathrm{C}$, 
following an additional incubation with $1 \mathrm{ml}$ of $5 \mu \mathrm{Ci} / \mathrm{ml}\left[{ }^{3} \mathrm{H}\right]$ leucine in RPMI medium for $30 \mathrm{~min}$ at $37^{\circ} \mathrm{C}$. Cells were washed three times with PBS and solubilized with $1 \mathrm{ml}$ lysis buffer (5\% SDS, $20 \mathrm{mM} \mathrm{Na} \mathrm{CO}_{3}$ and $2 \mathrm{mM}$ EDTA). Cellular radioactivity was measured in a scintillation counter.

\section{Glucose uptake and lipogenesis in primary adipocytes}

Fractions $(200 \mu \mathrm{l})$ of primary adipocytes (with a cytocrite of $50 \%$ ), incubated in DMEM medium containing $1 \%$ insulin-free $\mathrm{BSA}$, were stimulated with $100 \mathrm{nM}$ insulin for $30 \mathrm{~min}$ at $37^{\circ} \mathrm{C}$. Cells were then incubated at $37^{\circ} \mathrm{C}$ with $200 \mu \mathrm{l} \quad 0 \cdot 5 \mu \mathrm{Ci} / \mathrm{ml}$ $\left[{ }^{14} \mathrm{C}\right]$ glucose in the same buffer. Glucose uptake (and generation of glucose metabolites) as well as lipogenesis were measured for a period of $30 \mathrm{~min}$ and $2 \mathrm{~h}$ respectively. Cells were separated from free $\left[{ }^{14} \mathrm{C}\right]$ glucose using dinonylphtalate oil and cellular radioactivity was measured using regular or hydrophobic extraction scintillation as described previously (Karnieli et al. 1981, Cherqui et al. 1986).

\section{Western blot analysis}

Infected cells were washed two times with PBS, and harvested in buffer A $(25 \mathrm{mM}$ Tris- $\mathrm{HCl}$, $2 \mathrm{mM}$ sodium orthovanadate, $0.5 \mathrm{mM}$ EGTA, $10 \mathrm{mM} \mathrm{NaF}, 10 \mathrm{mM}$ sodium pyrophosphate, $80 \mathrm{mM} \beta$-glycerophosphate, $25 \mathrm{mM} \mathrm{NaCl}, 1 \%$ $\mathrm{Tx}-100$ and protease inhibitor cocktail 1:1000, $\mathrm{pH}$ $7 \cdot 4)$. For primary adipocytes, four freeze-thaw cycles were added. Cells were centrifuged at $12000 \mathrm{~g}$ for $20 \mathrm{~min}$ at $4{ }^{\circ} \mathrm{C}$, and the supernatant was collected. Samples of $100 \mu \mathrm{g}$ were resolved by SDS-PAGE under reducing conditions, and were transferred into nitrocellulose membrane for Western blotting with the indicated antibodies.

\section{Thymidine incorporation}

Fao cells (at 50\% confluence) in $35 \mathrm{~mm}$ dishes were incubated for $30 \mathrm{~h}$ in serum-free RPMI medium, prior to infection with vaccinia virus. Six hours post infection cells were treated with $100 \mathrm{nM}$ insulin for $14 \mathrm{~h}$ at $37^{\circ} \mathrm{C}$. At the end of incubation the medium was replaced with $1 \mathrm{ml}$ serum-free RPMI medium, containing $0.5 \mu \mathrm{Ci} / \mathrm{ml}\left[{ }^{3} \mathrm{H}\right]$ thymidine, and incubation was continued for $2 \mathrm{~h}$ at $37^{\circ} \mathrm{C}$. Cells were washed three times with PBS and were incubated for $30 \mathrm{~min}$ at $4{ }^{\circ} \mathrm{C}$ in $0.5 \mathrm{ml}$ ice-cold $7 \cdot 5 \%$ trichloroacetic acid. The cells were washed twice with $98 \%$ ice-cold ethanol, dissolved in $0.5 \mathrm{ml} 0 \cdot 1 \mathrm{M}$ $\mathrm{NaOH}$, and counted using a scintillation cocktail.

\section{Concentration of IR on wheat germ agglutinin column}

Primary adipocytes or Fao cells were solubilized at $4{ }^{\circ} \mathrm{C}$ in buffer A. Cells were centrifuged at $12000 \mathrm{~g}$ for $15 \mathrm{~min}$ at $4{ }^{\circ} \mathrm{C}$, and the supernatants were collected. Aliquots containing $0 \cdot 5-1 \cdot 0 \mathrm{mg}$ protein were incubated for $1 \mathrm{~h}$ at $4{ }^{\circ} \mathrm{C}$ with wheat germ agglutinin agarose beads. The complexes were washed three times with buffer B, and once with buffer $\mathrm{B}$ deprived of detergents. Immobilized IR was released from the beads by boiling in Laemmli's 'sample buffer' (Laemmli 1970), resolved by means of $7 \cdot 5 \%$ SDS-PAGE, and Western-blotted with IR or P-Tyr antibodies.

\section{Immunoprecipitation}

Primary adipocytes were solubilized at $4{ }^{\circ} \mathrm{C}$ in buffer A. Cells were centrifuged at $12000 \boldsymbol{g}$ for $15 \mathrm{~min}$ at $4{ }^{\circ} \mathrm{C}$, and the supernatants were collected. Aliquots containing $0.5-1.0 \mathrm{mg}$ protein were incubated for $2 \mathrm{~h}$ at $4{ }^{\circ} \mathrm{C}$ with IRS- 1 antibodies coupled to $60 \mu \mathrm{l}$ protein A-Sepharose beads (50\%). Immunocomplexes were washed three times with buffer A, and once with buffer A deprived of detergents. Immunocomplexes were resolved by means of $7 \cdot 5 \%$ SDS-PAGE and Western-blotted using IRS-1, P-Tyr or p $85 \alpha-P I 3 K$ antibodies.

\section{RESULTS}

\section{Infection with a recombinant vaccinia virus is an efficient means to quantitatively introduce proteins and peptides into primary adipocytes and rat hepatoma Fao cells}

Recombinant vaccinia viruses Vcc- $\beta$-Gal, Vcc-CT and Vcc-JM (i.e. recombinant vaccinia viruses containing $\beta$-Gal gene, IR-CT region gene and IR-JM region gene respectively) were isolated as outlined in Fig. 1 and described in the Materials and Methods section. In addition to the JM or the $\mathrm{CT}$ polypeptides, these viruses also expressed a variant of the bacterial $\beta$-galactosidase gene, under the control of the early/late vaccinia virus promoter, so that it is continuously expressed (Chakrabarti et al. 1997, Moss \& Earl 1991). Primary adipocytes and rat hepatoma Fao cells were infected with the recombinant viruses. The efficiency of infection was assessed by in vivo X-Gal staining of cells infected with Vcc- $\beta$-Gal at a m.o.i. of $10 \mathrm{pfu} / \mathrm{cell}$. As shown in Fig. $2 \mathrm{~B}$, more than $95 \%$ of the infected Fao cells produced $\beta$-Gal activity, as judged by the number of blue cells, while non-infected cells exhibited no blue color in the presence of the $\beta$-galactosidase 


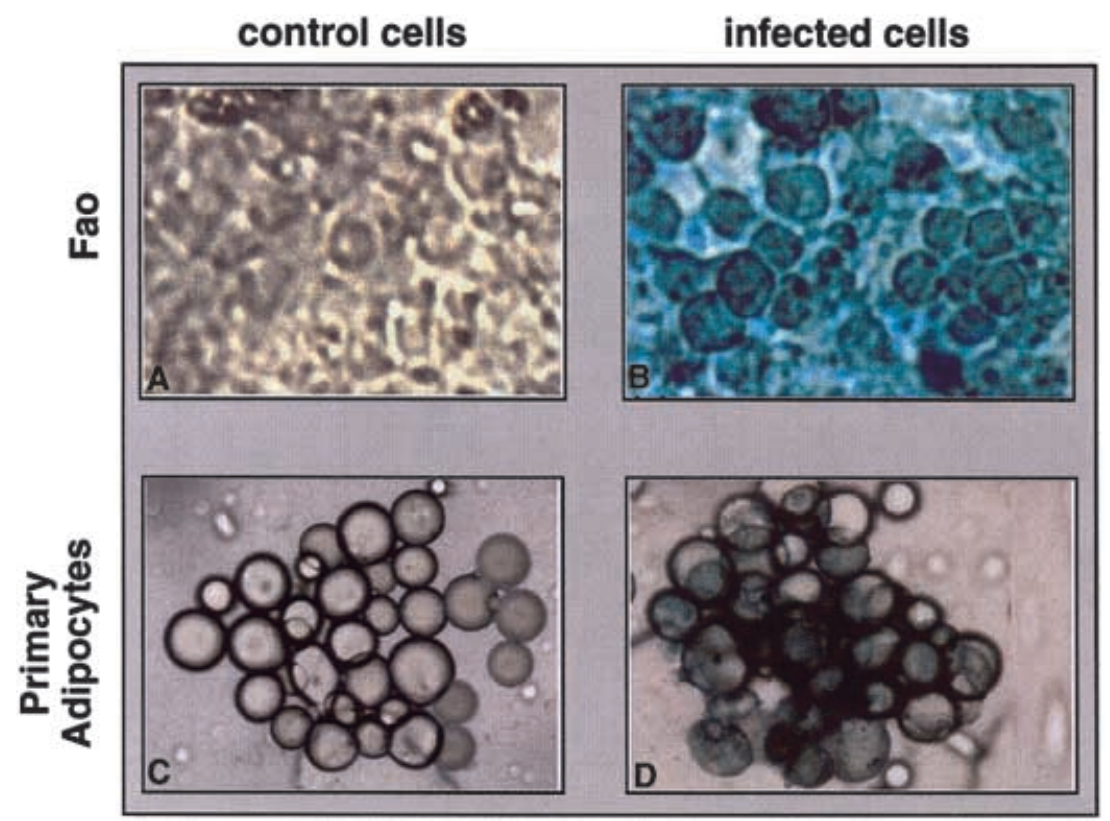

FIGURE 2. In vivo $\beta$-Gal staining of infected cells. Rat hepatoma Fao cells (A and $\mathrm{B})$, or primary adipocytes $(\mathrm{C}$ and $\mathrm{D})$ were infected with a recombinant vaccinia virus coding for the $\beta-\mathrm{Gal}$ gene (Vcc- $\beta-\mathrm{Gal})$. Twenty-four hours post infection, an in situ $\beta$-Gal staining was performed as described in the Materials and Methods section. The infection efficiency was evaluated by the number of cells stained blue in the presence of the $\beta$-galactosidase chromogenic substrate, X-Gal.

chromogenic substrate (Fig. 2A). Similar results were obtained with primary rat adipocytes (Fig. 2C and D); about $80 \%$ of the Vcc- $\beta$-Gal-infected cells were stained blue when treated with $\mathrm{X}-\mathrm{Gal}$. The infection did not alter the morphological features of either Fao cells or primary adipocytes. These results indicate that infection with a vaccinia virus is a promising technique to produce high expression levels of proteins and polypeptides in hepatoma cells and primary adipocytes.

\section{The JM and CT regions of IR are quantitatively expressed in hepatoma cells and primary adipocytes}

Rat adipocytes and Fao cells were infected at m.o.i. of $10 \mathrm{pfu} / \mathrm{cell}$ with Vcc- $\beta-G a l$, Vcc-CT or Vcc-JM. As shown in Fig. 3, high expression levels of both the $\mathrm{CT}$ and the JM regions of IR were observed in both cell types, 6 and $20 \mathrm{~h}$ following infection. Hence, a 6-h infection period was sufficient to obtain maximal expression levels of the peptides of interest. Using the T7-tag antibodies we found that Fao cells expressed similar levels of the JM and CT polypeptides, while primary adipocytes expressed higher levels of the C'T domain. These observations
(A)

(B)

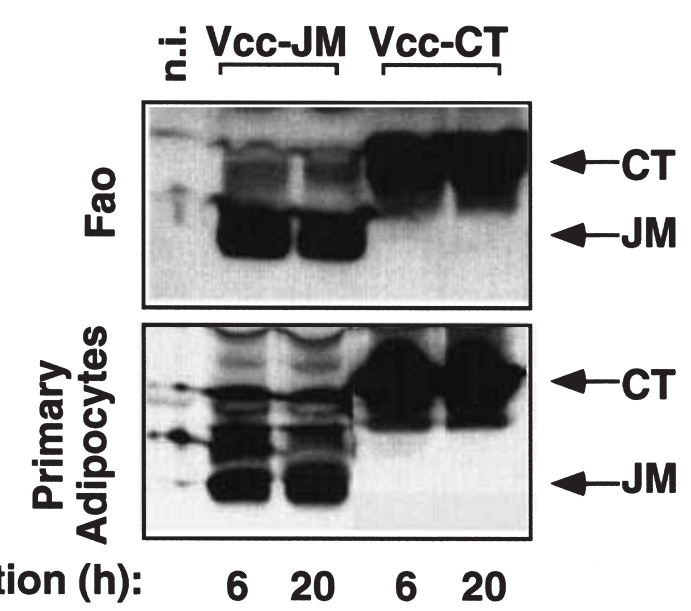

\section{Infection (h): $\quad \begin{array}{llll}6 & 20 & 6 & 20\end{array}$}

FIGURE 3. Overexpression of IR-derived JM and CT domains in Fao cells and primary adipocytes. Rat hepatoma Fao cells (A) or primary adipocytes (B) were infected with a recombinant vaccinia virus coding for T7-tagged fusion peptides corresponding to 41 amino acids (a.a. 943-984) of the JM region of IR (Vcc-JM), or 86 amino acids (a.a. 1245-1331) of the C-terminal region of IR (Vcc-CT). Cellular extracts were prepared, and samples $(100 \mu \mathrm{g})$ were resolved by means of $12 \%$ SDS-PAGE, and immunoblotted with T7-tag antibody. n.i., non infected. 


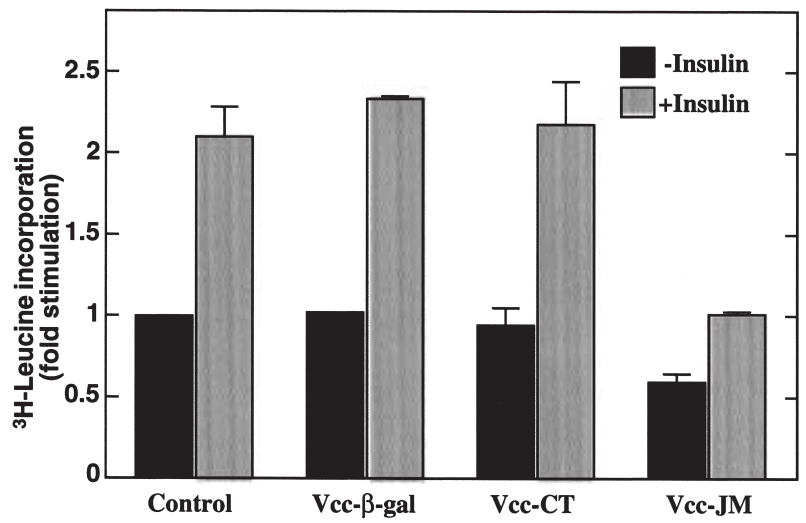

FIGURE 4. Insulin-induced amino acid uptake and utilization in infected Fao cells. Rat hepatoma Fao cells were infected with the indicated recombinant vaccinia virus as described in the Materials and Methods section. Following $6 \mathrm{~h}$ infection, cells were incubated at $37^{\circ} \mathrm{C}$ with or without $100 \mathrm{nM}$ insulin for $30 \mathrm{~min}$, then amino acid uptake and utilization were measured using $\left[{ }^{3} \mathrm{H}\right]$ leucine, as described in Materials and Methods. Results are means \pm S.D. of a representative experiment repeated twice in duplicates.

were confirmed following Coomassie Blue staining of cell extracts that revealed the presence of protein bands corresponding to the JM and CT polypeptides.

\section{Overexpression of the JM polypeptide inhibits insulin-stimulated uptake and utilization of amino acid by Fao cells}

An important biological effect of insulin is the regulation of nutrient content by increased hepatic amino acid uptake (Prentki et al. 1981). To determine the effects of the overexpressed IR domains on insulin-induced utilization of amino acids, Fao hepatoma cells were infected with Vcc- $\beta-G a l, ~ V c c-C T$ or Vcc-JM and the cellular content of $\left[{ }^{3} \mathrm{H}\right]$ leucine (and its metabolites) was measured $6 \mathrm{~h}$ post infection. In non-infected cells insulin stimulated Leu uptake twofold, which reflects the combined effects of insulin on Leu transport, Leu incorporation into proteins and Leu metabolism (Fig. 4). Leucine uptake was not affected by infection and overexpression of $\beta$-Gal or the CT region of IR. In contrast, overexpression of the JM region of IR presumably acted as a negative dominant inhibitor, and markedly inhibited ( $\sim 70 \%)$ the stimulatory effects of insulin on amino acid uptake. These results suggest that the JM region of IR plays an important role in mediating insulininduced utilization of amino acids by hepatoma cells.

www.endocrinology.org
A

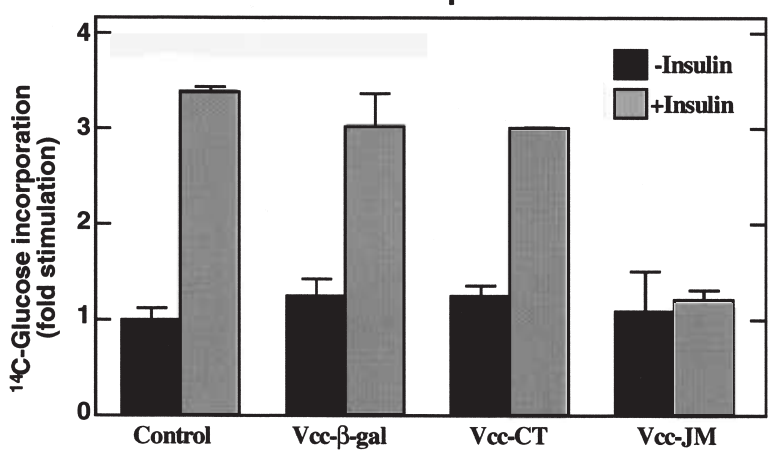

B

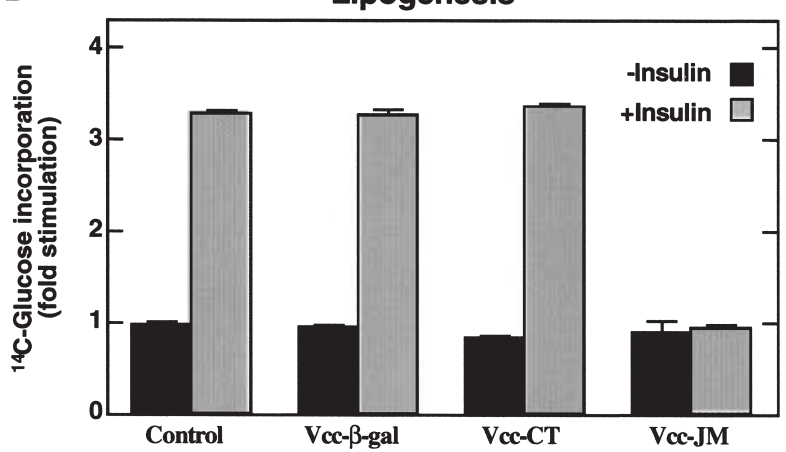

FIGURE 5. Insulin-induced glucose uptake and lipogenesis in infected primary adipocytes. Primary adipocytes were infected with the indicated recombinant vaccinia virus as described in the Materials and Methods section. Following $6 \mathrm{~h}$ infection, cells were incubated at $37^{\circ} \mathrm{C}$ with or without $100 \mathrm{nM}$ insulin for $30 \mathrm{~min}$, then glucose uptake and utilization (A) and lipogenesis (B) were assayed using $\left[{ }^{14} \mathrm{C}\right]$ glucose, as described in Materials and Methods. Results are means \pm S.D. of a representative experiments repeated three times in duplicates.

\section{Overexpression of the JM, but not the CT domain of IR, inhibits insulin-stimulated glucose utilization in primary rat adipocytes}

The effects of overexpressing the JM or CT domains of IR on insulin-stimulated metabolic functions in primary adipocytes were next evaluated. Consistent with previous studies carried out with 3T3-L1 adipocytes (Chen et al. 1997), vaccinia virus infection per se did not interfere with insulin-stimulated glucose uptake. As shown in Fig. $5 \mathrm{~A}$, insulin stimulated a three- to fourfold increase in the cellular content of $\left[{ }^{14} \mathrm{C}\right]$ glucose (and its metabolites) in non-infected adipocytes or in adipocytes infected with Vcc- $\beta-$ Gal or Vcc-CT. In 
contrast, overexpression of the JM domain abolished the stimulatory effects of insulin on glucose uptake and utilization, without affecting the basal activity. To further characterize the effects of the overexpressed JM domain, insulin-stimulated incorporation of $\left[{ }^{14} \mathrm{C}\right]$ glucose into lipids was measured. As demonstrated in Fig. 5B, insulin stimulated threefold the rate of lipogenesis in non-infected, Vcc- $\beta$-Gal infected or Vcc-CT infected cells, while overexpression of the isolated JM domain inhibited insulin-stimulated lipogenesis. These findings suggest that the overexpressed JM domain acts in a dominant negative fashion, and support the notion that this region of IR plays a crucial role in mediating insulin's metabolic functions.

\section{Overexpression of the isolated JM domain does not interfere with insulin binding or receptor autophosphorylation}

To determine whether the inhibitory effects of the isolated JM domain on insulin-induced metabolic functions were not secondary to inhibition of insulin binding, the ability of cell surface receptors to bind insulin was measured in control and infected cells. Non-infected as well as Vcc- $\beta-G a l$ infected Fao cells or primary adipocytes bound $\left.{ }^{125} \mathrm{I}\right]$ insulin to a similar extent as Vcc-CT and Vcc-JM infected cells (not shown). Likewise, insulin-induced autophosphorylation of the receptor $\beta$-subunits in both cell types was unaltered following overexpression of the isolated JM or CT domains (Fig. 6). These results indicate that the presence of free intracellular domains of IR has no effect on the assembly of IR heterotetramer, nor does it interfere with insulin binding to the receptor or with the intrinsic function of the receptor as a protein tyrosine kinase.

\section{Overexpression of the isolated JM domain inhibits insulin-stimulated Tyr phosphorylation of IRS-1, and activation of PI3K, PKB and p70 S6 kinase}

Tyrosine phosphorylation of IRS proteins is required for insulin-mediated glucose transport and amino acid uptake (Cheatham \& Kahn 1995). We have previously shown that IRS-1 and IRS-2 selectively interact with immobilized peptides comprising the JM region of IR (Paz et al. 1996, 1997), an interaction that presumably involves the PTB domain of the IRS proteins (Eck et al. 1996). Hence, the overexpressed IR-derived JM domains could competitively inhibit the interactions between the IR and the PTB domains of the endogenous

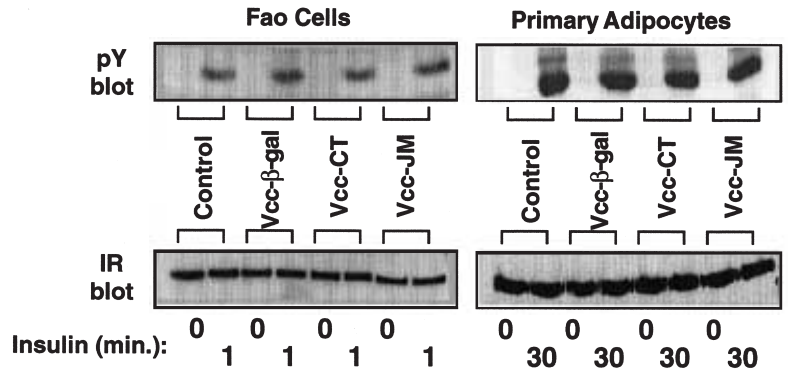

FIGURE 6. Effect of overexpression of the JM or CT domains on IR autophosphorylation. Rat hepatoma Fao cells or primary adipocytes were infected with the indicated recombinant vaccinia virus. Following $6 \mathrm{~h}$ infection cells were incubated with $100 \mathrm{nM}$ insulin at $37^{\circ} \mathrm{C}$ for the indicated periods of time. Cellular extracts were prepared and samples $(500 \mu \mathrm{g}$ Fao extracts; $1 \mathrm{mg}$ adipocytes extracts) were incubated with immobilized WGA, as described in Materials and Methods.

Complexes were eluted with Laemmli's 'sample buffer', resolved by means of $7 \cdot 5 \%$ SDS-PAGE and immunoblotted with P-Tyr and IR antibodies. Results are of a representative experiment, reproduced twice.

IRS proteins and, as a result, inhibit their Tyr phosphorylation following activation of IRK. To address this possibility, extracts, derived from insulin-stimulated Fao cells and primary adipocytes, overexpressing the $\mathrm{CT}$ or the JM domains of IR, were immunoprecipitated with IRS-1-specific antibodies followed by Western immunoblotting with P-Tyr antibodies. As shown in Fig. 7A, the $180 \mathrm{kDa}$ band, representing the IRS proteins, underwent $\mathrm{Tyr}$ phosphorylation in response to insulin in non-infected Fao cells, and in cells infected with Vcc- $\beta-G a l$ or Vcc-CT. In contrast, insulin-stimulated $\mathrm{Tyr}$ phosphorylation of IRS proteins in Vcc-JM-infected Fao cells was inhibited 70-80\%. Similar results were obtained with primary adipocytes (Fig. 7B). These findings support the notion that $\mathrm{Tyr}$ phosphorylation of IRS proteins depends upon interactions between IRS proteins and the JM domain of IR, which is required for mediating insulin-induced metabolic effects.

Tyrosine-phosphorylated IRS-1 can associate with, and stimulate the activity of, PI3K (Hadari et al. 1992). This results in phosphorylation and activation of downstream Ser/Thr kinases such as PDK-1, PKB and p70 S6K (Stokoe et al. 1997, Alessi et al. 1996, 1997, 1998). To determine which of the downstream effectors of IRS-1 are affected when its $\mathrm{Tyr}$ phosphorylation is inhibited we assayed for the association of $\mathrm{p} 85 \alpha$, the regulatory subunit of PI3K, with immunoprecipitated IRS-1 in infected Fao cells. As demonstrated in Fig. 8, 
A

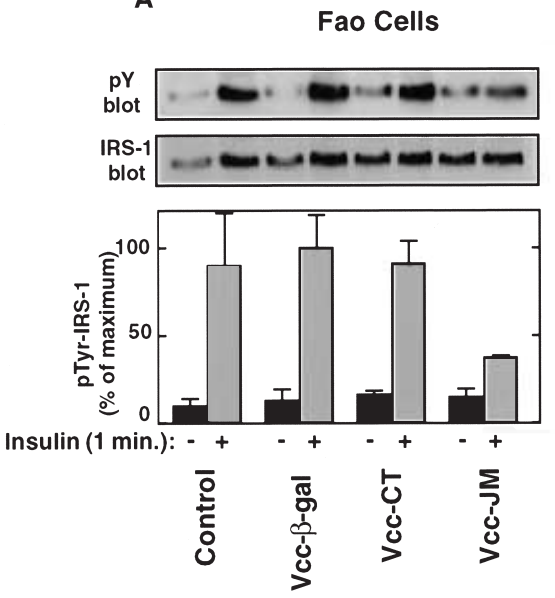

B

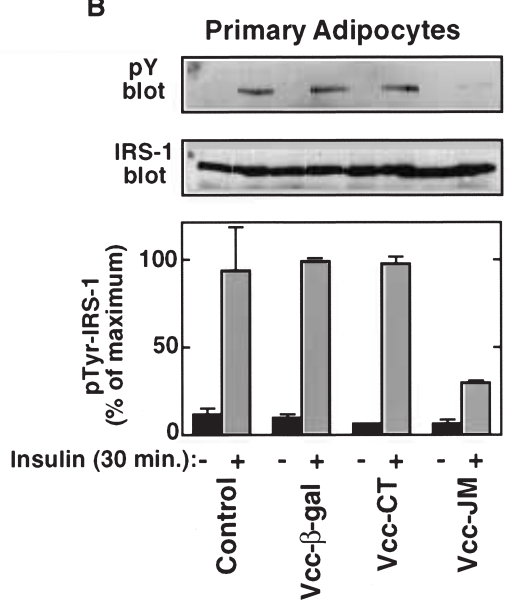

FIGURE 7. Effect of overexpression of the JM or CT domains on insulinstimulated IRS-1 phosphorylation. Rat hepatoma Fao cells (A) or primary adipocytes (B) were infected with the indicated recombinant vaccinia virus as described in Materials and Methods. Following $6 \mathrm{~h}$ infection, cells were incubated with $100 \mathrm{nM}$ insulin at $37^{\circ} \mathrm{C}$ for the indicated periods of time. Cellular extracts of Fao cells (A) or primary adipocytes (B) were prepared and $500 \mu \mathrm{g}(\mathrm{A})$ or $1 \mathrm{mg}$ (B) samples were subjected to immunoprecipitation (IP) with IRS-1 antibody. Immunocomplexes were resolved by means of $7 \cdot 5 \%$ SDSPAGE and immunoblotted with P-Tyr and IRS-1 antibodies. Quantitation of the intensity of the bands corresponding to P-Tyr-IRS-1 is presented as bar graphs. Results are means \pm S.D. of two independent experiments.

insulin stimulation resulted in the association of p85 $\alpha$ with Tyr-phosphorylated IRS-1 in noninfected cells or cells infected with Vcc- $\beta-G a l$ or Vcc-CT. In contrast, overexpression of the JM region largely inhibited the insulin-induced association of IRS-1 with $\mathrm{p} 85 \alpha$. The selective inhibitory effects of the overexpressed JM domain were accompanied by a decrease in insulin-dependent phosphorylation of both PKB (Fig. 9A) and p70 S6K (Fig. 9B). These results are consistent with the notion that the interactions of IRS-1 with the JM but not the CT domain of the IR are required for proper Tyr phosphorylation of IRS-1, its interactions with downstream effectors, and the induction of metabolic functions such as utilization of glucose and amino acids in physiologically insulinresponsive cells.

\section{Overexpression of the JM domain inhibits insulin-stimulated DNA synthesis}

The effects of the overexpressed receptor domains on insulin-stimulated DNA synthesis were next evaluated. As shown in Fig. 10, insulin stimulated three- to fourfold $\left[{ }^{3} \mathrm{H}\right]$ thymidine incorporation into DNA in non-infected Fao cells or in cells infected

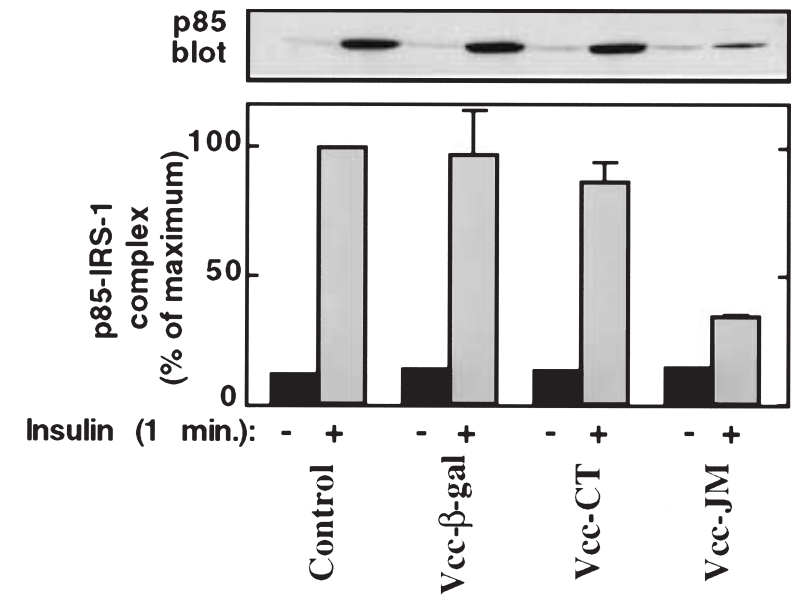

FIGURE 8. Effect of overexpression of the JM or CT domains on IRS-1-PI3K complex formation. Rat hepatoma Fao cells were infected with the indicated recombinant vaccinia virus. Following $6 \mathrm{~h}$ infection, cells were incubated with $100 \mathrm{nM}$ insulin for $1 \mathrm{~min}$ at $37^{\circ} \mathrm{C}$, and cellular extracts were prepared. Samples $(500 \mu \mathrm{g})$ were subjected to immunoprecipitation (IP) with IRS-1 antibody. Immunocomplexes were resolved by means of $7 \cdot 5 \%$ SDS-PAGE and immunoblotted with p $85 \alpha-$ PI3K antibodies. Quantitation of the intensity of the bands corresponding to $\mathrm{p} 85-\mathrm{PI} 3 \mathrm{~K}$ is presented as bar graphs. Results are means \pm S.D. of two independent experiments. 


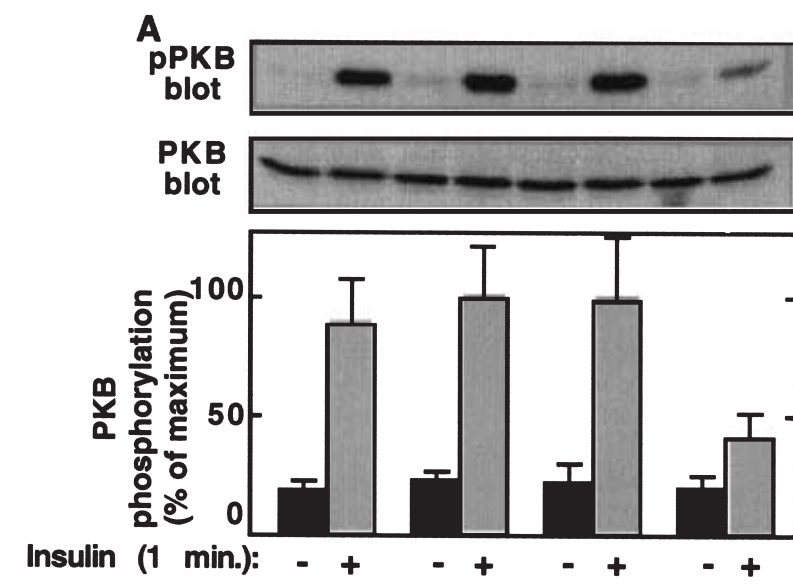

B
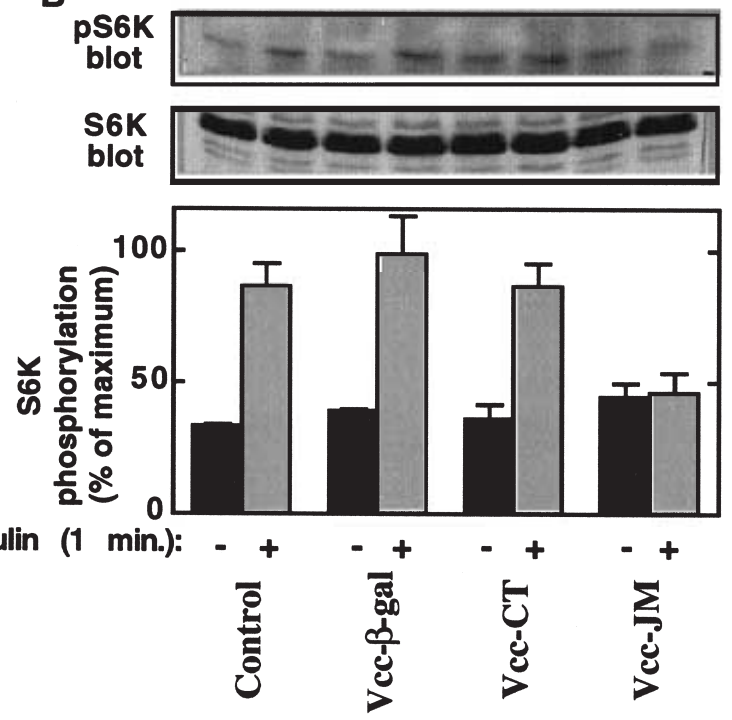

FIGURE 9. Effect of overexpression of the JM or CT domains on PKB and p70 S6K phosphorylation. Rat hepatoma Fao cells were infected with the indicated recombinant vaccinia virus. Following $6 \mathrm{~h}$ infection, cells were incubated with $100 \mathrm{nM}$ insulin for $1 \mathrm{~min}$ at $37{ }^{\circ} \mathrm{C}$, and cellular extracts were prepared. (A) Samples $(100 \mu \mathrm{g})$ were resolved by means of $7 \cdot 5 \%$ SDS-PAGE and immunoblotted with PKB and phospho-specific $\mathrm{PKB}$ antibodies. Results are means \pm S.D. of three independent experiments; (B) same as in (A) except that p70 S6K and phospho-specific p70 S6K antibodies were used. Quantitation of the intensity of the bands corresponding to phospho-specific PKB and phosphospecific p70 S6K is presented as bar graphs. Results are means \pm S.D. of two independent experiments.

with Vcc- $\beta$-Gal or Vcc-CT. In contrast, overexpression of the JM domain partially abolished $(\sim 40 \%)$ the stimulatory effects of insulin on

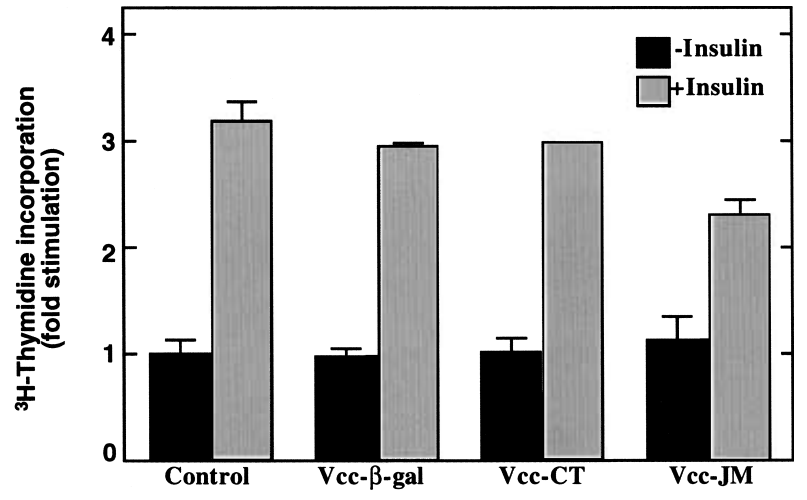

FIGURE 10. Insulin-induced thymidine incorporation in infected Fao cells. Rat hepatoma Fao cells were infected with the indicated recombinant vaccinia virus. Following $6 \mathrm{~h}$ infection, cells were incubated at $37^{\circ} \mathrm{C}$ with or without $100 \mathrm{nM}$ insulin for $14 \mathrm{~h}$. Thymidine incorporation was measured using $\left[{ }^{3} \mathrm{H}\right]$ thymidine, as described in the Materials and Methods section. Results are means \pm S.D. of a representative experiment carried out four times in duplicates.

$\left[{ }^{3} \mathrm{H}\right]$ thymidine incorporation into DNA. Hence, insulin-induced growth-promoting functions were also inhibited by the overexpressed JM polypeptide. These results implicate the JM domain as an essential element required for mediating both metabolic and growth-promoting effects of insulin.

\section{DISCUSSION}

The introduction of truncated/mutated forms of the IR into a number of cell lines enabled distinct roles to be assigned to different receptor regions in modulating the biological effects of insulin (Maegawa et al. 1988, Thies et al. 1989, Tavare \& Siddle 1993, Gustafson et al. 1995, Chaika et al. 1999). Still, all cell lines studied, including differentiated 3T3-L1 adipocytes, were at best high-fidelity models but they fall short of being physiological insulin-responsive tissues. Studies with transgenic mice, harboring altered receptors could provide the desired answers, but the current repertoire of these models is rather limited.

Primary adipocytes are a major target tissue for insulin action, however these fully differentiated cells are not readily amenable to genetic manipulations. To overcome this problem we set out to develop an alternative method that enables a rapid and quantitative expression of proteins of interest in primary adipose cells. This system makes use of a vaccinia virus that serves as an efficient vector for expressing genes of interest within the cytoplasm of 
eukaryotic cells (Moss \& Earl 1991). This approach provides several advantages: first, infection with vaccinia virus enables quantitative, high expression level of peptides/proteins in the majority $(>80 \%)$ of the infected cells $6 \mathrm{~h}$ post-infection. This enables us to study the effects of the introduced protein on any desired cellular function using the entire cell population, while eliminating the need to co-infect with a reporter gene that monitors a selective cellular response. Secondly, infection with a vaccinia virus per se or with an irrelevant protein such as $\beta$-galactosidase does not impair insulin responsiveness of the transfected cells; it does not alter insulin binding, nor does it affect the ability of insulin to activate the IRK and induce receptor autophosphorylation. Similarly, infection and expression of an irrelevant protein did not have any detrimental effects on insulin action and comparable levels of insulin-stimulated glucose utilization and lipogenesis (in adipocytes) or amino acids utilization (in Fao cells) were observed in non-infected cells, or in cells infected with $\beta$-galactosidase.

Previous studies furthered the notion that the IR mediates its interaction with downstream effector molecules through different domains within its cytoplasmic tail (Maegawa et al. 1988, White et al. 1988, Tavare \& Siddle 1993, Gustafson et al. 1995, Hansen et al. 1996, O’Neill et al. 1996, Chaika et al. 1999). Here we assessed the contribution of these domains to the metabolic effects of insulin in physiological insulin-responsive primary rat adipocytes, as well as in Fao hepatoma cells. We show that infection with a recombinant virus results in quantitative expression of the JM and CT domains in amounts exceeding by far the concentration of the endogenous receptor. We have previously shown (Paz et al. 1996) that expression of recombinant JM or CT domains in bacteria yields functional polypeptides that effectively interact with downstream effectors of the IR, such as IRS and Shc proteins. Therefore, we can assume that the JM and C'T domains, overexpressed in vivo in primary adipocytes and hepatoma cells, act as dominant negative inhibitors of the corresponding domains of the endogenous receptors. Interestingly, fundamental differences were found when the effects of the overexpressed polypeptides were compared. When fat cells were infected with recombinant virus expressing the JM region of IR, insulinstimulated glucose uptake and utilization is almost completely blunted, without any significant effect on the basal activity. In contrast, infection with the $\mathrm{CT}$ domain of IR had no significant effect. These findings suggest that glucose uptake and utilization in primary adipocytes is presumably mediated by proteins that selectively interact with the JM domain of IR.
Overexpression of the JM and C'T domains could interfere with any of the elements constituting the signaling pathways leading to insulin-stimulated glucose transport and lipogenesis. Overexpression of the JM or CT domains did not affect insulin binding nor did it affect the insulin-stimulated receptor kinase activity, assessed by autophosphorylation of the IR in vivo. These findings suggest that the intramolecular interactions of the endogenous IR domains, a prerequisite for the receptor kinase activation (Hubbard 1997), are strong enough and therefore insensitive to the presence of the overexpressed JM and CT domains. In contrast, overexpression of the JM, but not the CT domains, eliminated the ability of the IRK to interact with, and phosphorylate the IRS proteins.

IRS proteins are key mediators of insulinstimulated glucose transport, mainly due to binding and activation of PI3K (Cheatham \& Kahn 1995). These proteins interact with the JM domain of IR through their PTB domains (Eck et al. 1996). Indeed, we have previously shown that an individually expressed JM region of IR contains all the structural information that enables it to interact with IRS-1 and IRS-2 (Paz et al. 1996, 1997). Our present findings place the interactions between the JM region of IR and the IRS proteins as a central event required to propagate insulin metabolic functions. These results are somewhat at variance with previous observations demonstrating that overexpression of the PTB/SAIN domains of IRS proteins in 3T3-L1 adipocytes inhibited insulin's ability to enhance the phosphorylation of IRS proteins, without interference with insulin-stimulated glucose transport in these cells (Sharma et al. 1997). Since glucose transport assayed in 3T3-L1 adipocytes was still inhibited by wortmannin, a PI3K inhibitor, it led to the conclusion that insulin may stimulate glucose transport by an alternative pathway, independent of the engagement of IRS proteins with the IR (Sharma et al. 1997). This alternative pathway could involve direct binding of PI3K to the CT domain of the IR. While we cannot rule out the possibility that proteins, different from IRS, interact with the JM domain to further propagate glucose transport through activation of PI3K, our findings rule out the possibility that interaction of proteins, including $\mathrm{PI} 3 \mathrm{~K}$, with the $\mathrm{CT}$ domain can provide an alternative pathway. Our results suggest that glucose transport and utilization in primary rat adipocytes depends solely upon interactions between downstream effectors and the JM domain of the IR, making the latter the key region involved in relaying insulin's metabolic function in physiological insulin responsive cells. 
The overexpressed JM domain presumably acted as a dominant negative inhibitor of IR-IRS-1 complex formation, thus interfering with the ability of IRS proteins to undergo insulin-induced Tyr phosphorylation. Since Tyr-phosphorylated IRS proteins serve as docking sites for several SH2domain containing proteins such as p85, the regulatory subunit of PI3K (Backer et al. 1992, Hadari et al. 1992), overexpression of the JM domain also inhibited activation of PI3K and its downstream effectors PKB (Alessi et al. 1996) and p70 S6K (Ming et al. 1994, Alessi et al. 1998), supporting the established notion that these enzymes are downstream targets of IRS/PI3K in rat adipocytes (Egawa et al. 1999).

In hepatocytes, a major insulin-induced biological effect is the regulation of nutrient uptake by increased amino acid uptake, leading to enhanced protein synthesis. Insulin-induced amino acid uptake requires several hours (Reid \& Reid 1987), however, the initiation of the insulin signal involves early changes in Ser/Thr phosphorylation of multiple intracellular proteins. Enhanced Ser/Thr phosphorylation of the ribosomal protein S6 (Lane et al. 1992) through activation of $\mathrm{p} 70$ S6 kinase (Mukhopadhyay et al. 1992, Thomas 1992) is one of the early biological responses to insulin that induces protein synthesis (Krieg et al. 1989). As shown here, interference with the ability of the JM domain to interact with downstream effectors decreased the ability of insulin to induce amino acid uptake and utilization. Hence, similar to lipogenesis, JM-effectors interactions are indispensable for insulin-induced metabolic effects in Fao cells. Insulin-induced DNA synthesis in Fao cells was less sensitive to the inhibitory effects of the overexpressed JM domain. These results could simply reflect the differences in assay conditions for measurements of amino acid utilization vs DNA synthesis. Alternatively, the growth-promoting activities of insulin could be mediated by proteins that better interact with Tyr-phosphorylated endogenous JM receptor domain, making them somewhat less sensitive to competition by the overexpressed non-phosphorylated JM region.

Several reasons could account for the insensitivity of the cells to the overexpressed CT domain. While we have previously shown (Paz et al. 1996) that the isolated CT region, expressed in bacteria as a $\mathrm{His}_{6}$-fusion peptide, maintains its structural characteristics and is capable of interacting with downstream effectors such as Shc, we cannot rule out the possibility that this domain when overexpressed in mammalian cells does not assume its native conformation or localization and therefore fails to act in a negative dominant fashion. Alternatively, the interactions of the isolated CT domain with its putative downstream effectors in vivo might be of low enough affinity such that it fails to act as a true negative dominant inhibitor. In that respect the overexpressed CT domain resembles the overexpressed CSF-1/IR chimera mutant, lacking 12 amino acids from its JM region, including the NPEY motif, which does not induce CSF1 mediated glucose transport when overexpressed in 3T3-L1 adipocytes, but fails to act as a negative dominant inhibitor of insulin-stimulated glucose transport, mediated by the endogenous IRs in these cells (Boehm et al. 1998). Finally, the inhibitory effects exerted by the JM, but not the CT, domain could not be attributed to selective Tyr phosphorylation of the former, since neither domain undergoes significant $\mathrm{Tyr}$ phosphorylation in response to insulin in infected cells $(\mathrm{K} \mathrm{Paz} \& \mathrm{Y}$ Zick, unpublished observations).

In summary, our data demonstrate the use of vaccinia virus-mediated gene transfer to introduce and functionally express various protein domains in physiologically insulin-responsive cells. Our findings suggest that interactions between the JM region of IR and its downstream effectors are obligatory for insulin-stimulated metabolic functions in physiologically relevant insulin-responsive cells. They also rule out the possibility that interaction of proteins, including PI3K, with the $\mathrm{CT}$ domain can provide an alternative pathway. In contrast, insulin-induced growth-promoting effects depend only partially upon interactions between the JM domain of IR and its downstream effectors. Further studies are therefore required to elucidate the molecular components that interact with the different IR domains and mediate insulin signal transduction in hepatoma cells and terminally differentiated primary adipocytes. The vaccinia virus-mediated protein expression system sets the stage for such studies.

\section{ACKNOWLEDGEMENTS}

We thank Dr Ronit Sagi-Eisenberg for helpful comments and discussions. This work was supported by research grants to $\mathrm{Y} Z$ from the following sources: Kekst Foundation; Ebner Family Biomedical Research Foundation; Crown Foundation; The Juvenile Diabetes Foundation International (1-1998-228); The MINERVA Foundation; and the Israel Science Foundation (founded by the Israel Academy of Sciences and Humanities). Y Z is an incumbent of the Philip Harris and Gerald Ronson Career Development Chair in Diabetes Research. 


\section{REFERENCES}

Alessi DR, Andjelkovic M, Caudwell B, Cron P, Morrice N, Cohen P \& Hemmings BA 1996 Mechanism of activation of protein kinase B by insulin and IGF-I. EMBO fournal 15 6541-6551.

Alessi DR, James SR, Downes CP, Holmes AB, Gaffney PR, Reese CB \& Cohen P 1997 Characterization of a 3 -phosphoinositide-dependent protein kinase which phosphorylates and activates protein kinase B alpha. Current Biology 7 261-269.

Alessi DR, Kozlowski MT, Weng QP, Morrice N \& Avruch J 1998 3-Phosphoinositide-dependent protein kinase 1 (PDK1) phosphorylates and activates the p70 S6 kinase in vivo and in vitro. Current Biology 8 69-81.

Backer JM, Myers MJ, Shoelson SE, Chin DJ, Sun XJ, Miralpeix M, Hu P, Margolis B, Skolnik EY, Schlessinger J \& White MF 1992 Phosphatidylinositol 3'-kinase is activated by association with IRS-1 during insulin stimulation. EMBO Fournal 11 3469-3479.

Begum N, Olefsky JM \& Draznin B 1993 Mechanism of impaired metabolic signaling by a truncated human insulin receptor. Decreased activation of protein phosphatase 1 by insulin. Fournal of Biological Chemistry 268 7917-7922.

Boehm JE, Chaika OV \& Lewis RE 1998 Anti-apoptotic signaling by a colony-stimulating factor-1 receptor/insulin receptor chimera with a juxtamembrane deletion. Fournal of Biological Chemistry 273 7169-7176.

Chaika OV, Chaika N, Volle DJ, Hayashi H, Ebina Y, Wang LM, Pierce JH \& Lewis RE 1999 Mutation of tyrosine 960 within the insulin receptor juxtamembrane domain impairs glucose transport but does not inhibit ligand-mediated phosphorylation of insulin receptor substrate-2 in 3T3-L1 adipocytes. Fournal of Biological Chemistry 274 12075-12080.

Chakrabarti S, Sisler JR \& Moss B 1997 Compact, synthetic, vaccinia virus early/late promoter for protein expression. BioTechniques 21 1904-1907.

Cheatham B \& Kahn CR 1995 Insulin action and insulin signaling network. Endocrine Reviews 16 117-142.

Chen D, Elmendorf JS, Olson AL, Li X, Earp HS \& Pessin JE 1997 Osmotic shock stimulates GLUT4 translocation in 3T3 L1 adipocytes by a novel tyrosine kinase pathway. Fournal of Biological Chemistry 272 27401-27410.

Cherqui G, Caron M, Wicek D, Lascols O, Capeau J \& Picard J 1986 Insulin stimulation of glucose metabolism in rat adipocytes: possible implication of protein kinase C. Endocrinology 118 1759-1769.

Cushman SW \& Salans LB 1978 Determinations of adipose cell size and number in suspensions of isolated rat and human adipose cells. Fournal of Lipid Research 19 269-273.

Ebina Y, Ellis L, Jarnagin K, Edery M, Graf L, Clauser E, Ou JH, Masiarz F, Kan Y, Goldfine ID, Roth RA \& Rutter WJ 1985 The human insulin receptor cDNA: the structural basis for hormone-activated transmembrane signalling. Cell $\mathbf{4 0}$ 747-758.

Eck MJ, Dhe PS, Trub T, Nolte RT \& Shoelson SE 1996 Structure of the IRS-1 PTB domain bound to the juxtamembrane region of the insulin receptor. Cell $\mathbf{8 5}$ 695-705.

Egawa K, Sharma PM, Nakashima N, Huang Y, Huver E, Boss GR \& Olefsky JM 1999 Membrane-targeted phosphatidylinositol 3-kinase mimics insulin actions and induces a state of cellular insulin resistance. Fournal of Biological Chemistry 274 14306-14314.

Faria TN, Blakesley VA, Kato H, Stannard B, LeRoith D \& Roberts CJ 1994 Role of the carboxyl-terminal domains of the insulin and insulin-like growth factor I receptors in receptor function. Fournal of Biological Chemistry 269 13922-13928.

Gustafson TA, He W, Craparo A, Schaub CD \& O'Neill T 1995 Phosphotyrosine-dependent interaction of SHC and insulin receptor substrate 1 with the insulin receptor via a novel non-SH2 domain. Molecular and Cellular Biology 15 2500-2508.

Hadari YR, Tzahar E, Nadiv O, Rothenberg P, Roberts CTJ, LeRoith D, Yarden Y \& Zick Y 1992 Insulin and insulinomimetic agents induce activation of phosphatidylinositol 3 '-kinase upon its association with pp185 (IRS-1) in intact rat livers. Fournal of Biological Chemistry 267 17483-17486.

Hansen H, Svensson U, Zhu J, Laviola L, Giorgino F, Wolf G, Smith RJ \& Riedel H 1996 Interaction between the Grb10 SH2 domain and the insulin receptor carboxyl terminus. Fournal of Biological Chemistry 271 8882-8886.

Haslam RJ, Kolde HB \& Hemmings BA 1993 Pleckstrin domain homology. Nature 363 309-310.

Hubbard SR 1997 Crystal structure of the activated insulin receptor tyrosine kinase in complex with peptide substrate and ATP analog. EMBO Fournal 16 5572-5581.

Kaburagi Y, Momomura K, Yamamoto-Honda R, Tobe K, Tamori Y, Sakura H, Akanuma Y, Yazaki Y \& Kadowaki T 1993 Site-directed mutagenesis of the juxtamembrane domain of the human insulin receptor. Fournal of Biological Chemistry 268 16610-16622.

Karnieli E, Zarnowski MJ, Hissin PJ, Simpson IA, Salans LB \& Cushman SW 1981 Insulin-stimulated translocation of glucose transport systems in the isolated rat adipose cells. Fournal of Biological Chemistry 256 4772-4777.

Krieg J, Hofsteenge J \& Thomas G 1989 Identification of the $40 \mathrm{~S}$ ribosomal protein S6 phosphorylation sites induced by cycloheximide. Fournal of Biological Chemistry 263 11473-11477.

Laemmli UK 1970 Cleavage of structural proteins during the assembly of the head of bacteriophage T4. Nature 227 680-685.

Lane HA, Morley SJ, Doree M, Kosma SC \& Thomas G 1992 Identification and early activation of a Xenopus laevis $\mathrm{p} 70^{\mathrm{s} 6 \mathrm{k}}$ following progesterone-induced meiotic maturation. EMBO Fournal 11 1743-1749.

Lavan BE, Fantin VR, Chang ET, Lane WS, Keller SR \& Lienhard GE 1997a A novel 160-kDa phosphotyrosine protein in insulin-treated embryonic kidney cells is a new member of the insulin receptor substrate family. Fournal of Biological Chemistry 272 21403-21407.

Lavan BE, Lane WS \& Lienhard GE $1997 b$ The 60-kDa phosphotyrosine protein in insulin-treated adipocytes is a new member of the insulin receptor substrate family. Fournal of Biological Chemistry 272 11439-11443.

Lawrence JC \& Larner J 1978 Activation of glycogen synthase in rat adipocytes by insulin and glucose involves increased glucose transport and phosphorylation. Fournal of Biological Chemistry 253 2104-2113.

Levy TR, Taouis M, Blaettler DH, Gorden P \& Taylor SI 1994 Insulin-induced activation of phosphatidyl inositol 3-kinase. Demonstration that the p85 subunit binds directly to the $\mathrm{COOH}$ terminus of the insulin receptor in intact cells. Fournal of Biological Chemistry 269 31178-31182.

Maegawa H, McClain DA, Freidenberg G, Olefsky JM, Napier M, Lipari T, Dull TJ, Lee J \& Ullrich A 1988 Properties of a human insulin receptor with a $\mathrm{COOH}$-terminal truncation. II. Truncated receptors have normal kinase activity but are defective in signaling metabolic effects. Fournal of Biological Chemistry 263 8912-8917. 
Mayer BJ, Ren R, Clark KL \& Baltimore D 1993 A putative modular domain present in diverse signaling proteins. Cell 73 629-630.

Ming X-F, Burgering BMT, Wennstrom S, Clawsson-Welsh L, Heldin C-H, Bos JL, Kozma SC \& Thomas G 1994 Activation of $\mathrm{p} 70 / \mathrm{p} 85$ S6 kinase by a pathway independent of p21 ${ }^{\text {ras }}$. Nature $371426-429$.

Moss B \& Earl PL 1991 In Current Protocols in Molecular

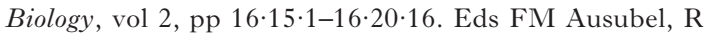
Brent, RE Kongston, DD Moore, JG Seidman, JA Smith \& K Struhl. New York: Greene Publishing Associates and Wiley-Interscience.

Mukhopadhyay NK, Price DJ, Kyriakis JM, Pelech S, Sanghera J \& Avruch J 1992 An array of insulin-activated, prolinedirected serine/threonine protein kinases phosphorylate the p70 S6 kinase. Fournal of Biological Chemistry 267 3325-3335.

O’Neill TJ, Rose DW, Pillay TS, Hotta K, Olefsky JM \& Gustafson TA 1996 Interaction of a GRB-IR splice variant (a human GRB10 homolog) with the insulin and insulin-like growth factor I receptors. Evidence for a role in mitogenic signaling. Fournal of Biological Chemistry $27122506-22513$.

Patti M-E, Sun X-J, Bruening JC, Araki E, Lipes MA, White MF \& Kahn CR 1995 4PS/insulin receptor substrate (IRS)-2 is the alternative substrate of the insulin receptor in IRS-1deficient mice. Fournal of Biological Chemistry 27024670 24673.

Paz K, Voliovitch H, Hadari YR, Roberts CT, LeRoith D \& Zick Y 1996 Interaction between the insulin receptor and its downstream effectors: use of individually expressed receptor domains for structure/function analysis. Fournal of Biological Chemistry 271 6998-7003.

Paz K, Hemi R, LeRoith R, Karasik A, Elhanany E, Kanety H \& Zick Y 1997 A molecular basis for insulin resistance: elevated serine/threonine phosphorylation of IRS-1 and IRS-2 inhibits their binding to the juxtamembrane region of the insulin receptor and impairs their ability to undergo insulin-induced tyrosine phosphorylation. Fournal of Biological Chemistry 272 29911-29918.

Prentki M, Crettaz M \& Jeanrenaud B 1981 Role of microtubules in insulin and glucagon stimulation of amino acid transport in isolated rat hepatocytes. Fournal of Biological Chemistry 256 4336-4340.

Pronk GJ, McGlade J, Pelicci G, Pawson T \& Bos JL 1993 Insulin-induced phosphorylation of the $46-$ and $52-\mathrm{kDa}$ Shc proteins. Fournal of Biological Chemistry 268 $5748-5753$.

Quon MJ, Butte AJ, Zarnowski MJ, Sesti G, Cushman SW \& Taylor SI 1994 Insulin receptor substrate 1 mediates the stimulatory effect of insulin on GLUT4 translocation in transfected rat adipose cells. Fournal of Biological Chemistry $26927920-27924$

Reid TW \& Reid WA 1987 The labile nature of the insulin signal(s) for the stimulation of DNA synthesis in mouse lens epithelial and 3T3 cells. Fournal of Biological Chemistry 262 229-233.

Sharma PM, Egawa K, Gustafson TA, Martin JL \& Olefsky JM 1997 Adenovirus-mediated overexpression of IRS-1 interacting domains abolishes insulin-stimulated mitogenesis without affecting glucose transport in 3T3-L1 adipocytes. Molecular and Cellular Biology 17 7386-7397.

Smith HJ, Pons S, Patti ME, Burks DJ, Yenush L, Sun XJ, Kahn CR \& White MF 1997 The $60 \mathrm{kDa}$ insulin receptor substrate functions like an IRS protein (pp60IRS3) in adipose cells. Biochemistry 36 8304-8310.

Stokoe D, Stephens LR, Copeland T, Gaffney PR, Reese CB, Painter GF, Holmes AB, McCormick F \& Hawkins PT 1997 Dual role of phosphatidylinositol-3,4,5-trisphosphate in the activation of protein kinase B. Science 277 $567-570$.

Sun XJ, Rothenberg P, Kahn CR, Backer JM, Araki E, Wilden PA, Cahill DA, Goldstein BJ \& White MF 1991 Structure of the insulin receptor substrate IRS-1 defines a unique signal transduction protein. Nature 352 73-77.

Sun X-J, Wang L-M, Zhang Y, Yenush L, Myers MG Jr, Glasheen E, Lane WS, Pierce JH \& White MF 1995 Role of IRS-2 in insulin and cytokine signalling. Nature 377 $173-177$.

Tanti JF, Grillo S, Gremeaux T, Coffer PJ, Van Obberghen E \& Le-Marchand Brustel Y 1997 Potential role of protein kinase $\mathrm{B}$ in glucose transporter 4 translocation in adipocytes. Endocrinology 138 2005-2010.

Tavare JM \& Siddle K 1993 Mutational analysis of insulin receptor function: consensus and controversy. Biochimica et Biophysica Acta 1178 21-39.

Thies RS, Ullrich A \& McClain DA 1989 Augmented mitogenesis and impaired metabolic signaling mediated by a truncated insulin receptor. Fournal of Biological Chemistry $26412820-12825$.

Thomas G 1992 MAP kinase by any other name smells just as sweet. Cell 68 3-6.

Ullrich A, Bell JR, Chen EY, Herrera R, Petruzelli LM, Dull TJ, Gray A, Coussens L, Liao YC, Tsubokawa M, Mason A, Seeburg PH, Grunfeld C, Rosen OM \& Ramachandran J 1985 Human insulin receptor and its relationship to the tyrosine kinase family of oncogenes. Nature $\mathbf{3 1 3}$ $756-761$.

White MF 1997 The insulin signalling system and the IRS proteins. Diabetologia $40 \mathrm{~S} 2-\mathrm{S} 7$.

White MF, Livingstone JN, Backer JM, Lauris V, Dull T, Ullrich A \& Kahn CR 1988 Mutation of the insulin receptor at tyrosine 960 inhibits signal transmission but does not affect its tyrosine kinase activity. Cell $\mathbf{5 4}$ 641-649.

Withers DJ, Gutierrez JS, Towery H, Burks DJ, Ren JM, Previs S, Zhang Y, Bernal D, Pons S, Shulman GI, Bonner WS \& White MF 1998 Disruption of IRS-2 causes type 2 diabetes in mice. Nature $391900-904$.

Yamauchi T, Tobe K, Tamemoto H, Ueki K, Kaburagi Y, Yamamoto HR, Takahashi Y, Yoshizawa F, Aizawa S, Akanuma Y, Sonenberg N, Yazaki Y \& Kadowaki T 1996 Insulin signalling and insulin actions in the muscles and livers of insulin-resistant, insulin receptor substrate 1-deficient mice. Molecular and Cellular Biology 16 3074-3084.

REVISED MANUSCRIPT RECEIVED 17 December 1999 